\title{
Capillary Haemangioma of Nasal Septum
}

\author{
Bestari J Budiman, Ricki Octiza
}

\begin{abstract}
Abstrak
Capillary haemangioma is a benign, rapidly growing lesion of the skin and mucous membranes. It may rarely present as a mass of considerable size and thus entirely fill the nasal cavity. Its etiology remains obscure. Capillary haemangioma usually involves the gingiva, lips, tongue, and buccal mucosa. However, the nasal cavity is a rare location for this lesion. The most common symptoms are unilateral epistaxis and nasal obstruction. The treatment of choice is surgery to remove the tumour even for large lesion. A case of capillary haemangioma at anterior nasal septal in 6 years old girl had been treated with extirpation.
\end{abstract}

Kata kunci: Capillary haemangioma, nasal septum, epistaxis, diagnosis, treatment

\section{Abstract}

Haemangioma kapiler merupakan suatu lesi jinak pada kulit dan mukosa dengan pertumbuhan yang cepat. Meskipun jarang berukuran besar, namun dapat memenuhi seluruh kavum nasi. Etiologinya sampai sekarang masih belum jelas. Haemangioma kapiler sering terdapat pada ginggiva, bibir, lidah dan mukosa bukal. Kavum nasi merupakan lokasi yang jarang terdapatnya haemangioma kapiler. Gejala yang paling sering adalah unilateral epistaksis dan sumbatan hidung. Pembedahan untuk mengangkat tumor ini merupakan terapi pilihan meskipun berukuran besar. Suatu kasus haemangioma kapiler septum anterior pada anak perempuan berumur 6 tahun telah dilakukan ekstirpasi sebagai terapi.

Keywords: Haemangioma kapiler, septum nasi, epistaksis, diagnosis, penatalaksanaan

Affiliasi penulis : Bagian Telinga Hidung Tenggorok Bedah KepalaLeher (THT-KL) Fakultas Kedokteran Universitas Andalas Korespondensi : Bestari J Budiman, Telp: 0751-810900

\section{INTRODUCTION}

Haemangioma is a benign neoplasm of vascular phenotype. ${ }^{1}$ Usually, congenital lesions are located on the skin or oral mucosa while the nasal cavity and paranasal sinuses are uncommon sites for haemangiomas. Nasal cavity haemangioma is extraordinarily rare in children. ${ }^{2}$

Mucosal haemangiomas of the nasal cavity, paranasal sinuses and nasopharynx account for $10 \%$ of all head and neck haemangiomas and approximately $25 \%$ of all non-epithelial neoplasms of this anatomical region. The haemangiomas occur in all ages, although there is a peak in children and adolescent males, females in the reproductive years, and then an equal distribution beyond 40 years of age. Patients with cavernous haemangiomas tend to be men in the $5^{\text {th }}$ decade. ${ }^{1,2}$

Haemangioma of nasal cavity also known as lobular capillary haemangioma, pyogenic granuloma, capillary haemangioma, cavernous haemangioma, epulis gravidarum. This various name of this tumor show that the exact pathogenesis is still continued debated. Some theories say that capillary haemangioma has an association with injury and hormonal factors. ${ }^{1,2,3,4}$

In the nasal cavity, anterior septum is the most frequently affected followed by turbinate but have also been described arising from the maxillary sinus, roof of the nasal cavity, and floor of the nasal vestibule. This disease usually presented as unilateral epistaxis and nasal obstruction.

Histologically, these masses are characterized by varying sized capillaries in lobular arrangements and anastomosing networks of capillaries, thus supporting the name lobular capillary haemangioma. Surrounding these lobules is a loose spindle cell proliferation of pericytic cells. Surgical excision is the treatment of lobular capillary haemangiomas. Intraoperative frozen sections may be necessary to confirm the diagnosis. ${ }^{3}$

\section{CASE REPORT}

A six years old girl came into emergency room's Dr.M.Djamil hospital Padang on November $14^{\text {th }}$ 2010 (MR 716907), with chief complain bleeding from left nostril since 2 hours before admission. The blood came when the patient was sleeping with amount approximately 5 teaspoon. No sign of trauma. History of nasal bleeding one week ago, approximately a half of glasses, spontaneously stop by it self. Since 1 week ago patient complaint about a mass was grown in her left nostril and obstruction her nose. Then her parents took her to otorhinolaringologyst and recommended for operation. No history of trauma to the nose. Left nostril was obstruction. No history of smelly discharge from the nose. No history of allergy.

General examination, condition was good, composmentis, temperature $37,3^{\circ} \mathrm{C}$, pulse rate $110 \mathrm{x} /$ minute. ENT examination, shape of nose was good, no sign of deviation. No saddle nose. Ear and throath no abnormality were found. Right nasal cavity was wide, inferior and medial turbinate eutrophy, no septal deviation. Left nasal cavity was narrowed, there is a reddish mass, at anterior septum, almost closed anterior nostril, rubbery, no fluctuation, no pain, no active bleeding and no ulceration. Inferior and medial turbinate cannot be evaluated.

Laboratory finding, $\mathrm{Hb}: 11,1 \mathrm{gr} / \mathrm{dl}$, leukocyte: 9500/ $\mathrm{mm}^{3}$, hematocrit: $30 \%$, trombocyte: 407.000/ $\mathrm{mm}^{3}$, PT: 10.9 second, APTT: 39.5 second.

Patient was diagnosed with post epistaxis caused by suspected haemangioma septum, differential diagnosed with granuloma septum. Patient was treated with amoxicillin clavulanate $3 \times 250 \mathrm{mg}$, 
tranexamic acid injection $3 \times 250 \mathrm{mg}$, vitamin $\mathrm{K} 3 \times 5 \mathrm{mg}$ and vitamin $\mathrm{C}$ injection $3 \times 30 \mathrm{mg}$. Patient was planned for extirpation under general anesthesia.

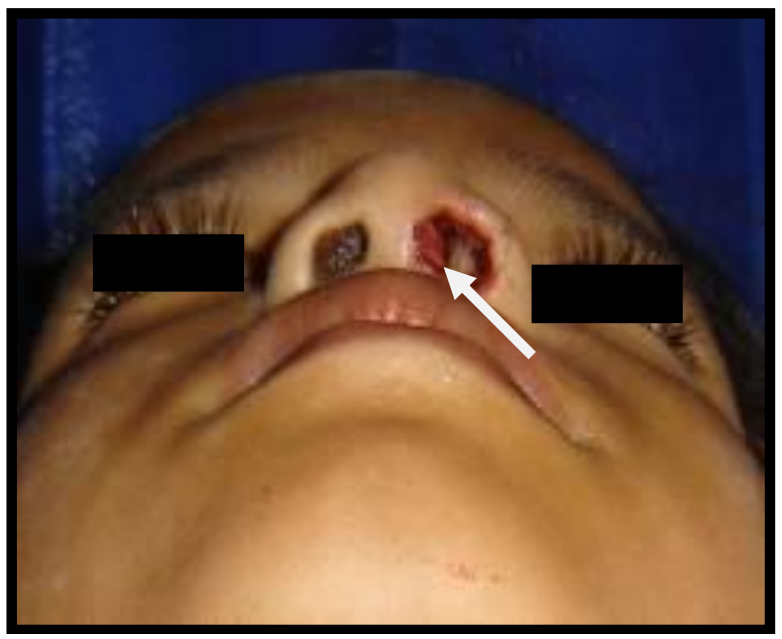

Figure 1. Haemangioma arising from left anterior septum

Two days after the patient was consulted to oncology subdepartment, with diagnosed suspected haemangioma septum, differential diagnosed with nasal septal granuloma. Transamin, vitamin $\mathrm{K}$ and vitamin $\mathrm{C}$ injection were stopped and antibiotic therapy was continued. Paranasal sinus CT Scan was planned. Patient was planned to go on extirpation under general anesthesia.

On November $19^{\text {th }} 2010$, CT Scan (C.2353) was performed with result "there was a mass in left nasal cavity which is push nasal septal to the right, isodense in density, clear edge, regular, no sign of cartilage destruction. Paranasal sinuses was clear, no mass at nasopharynx, no enlargement of lymph node. Conclusion : left nasal cavity tumor".

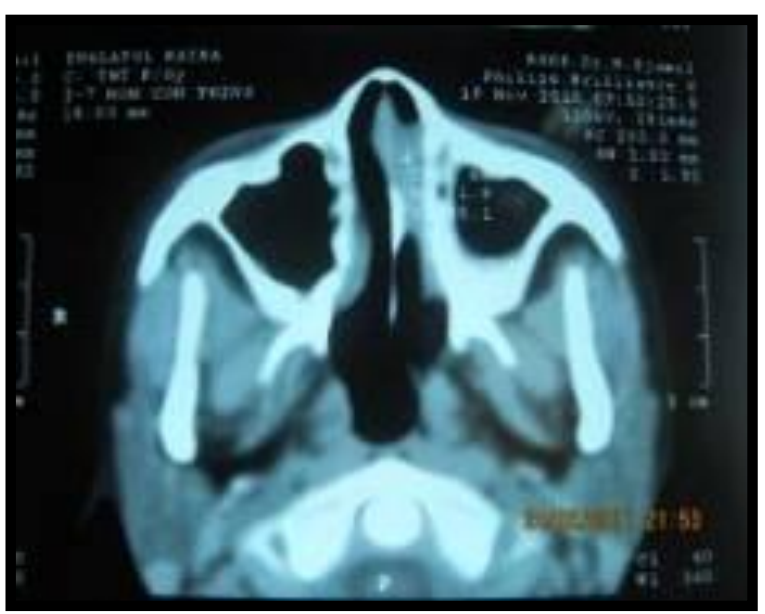

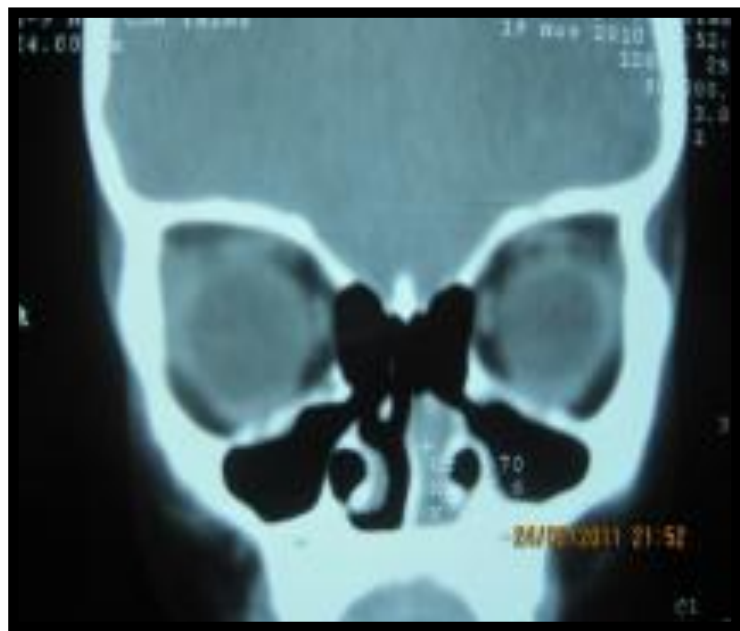

Figure 2. CT Scan axial and coronal showing mass at left nasal cavity

On November $22^{\text {th }}, 2010$ extirpation was perfomed under general anesthesia.

Operating report :

- Patient lying down on operating table under general anesthesia

- Septic/antiseptic procedure

- Applied oral packing

- Applied adrenaline : lidocaine tamponade 1:4 in the both nasal cavity.

- Evaluation, there was a reddish mass at anterior septum, easy to bleed, smooth surface. The lateral wall is free from lession.

- Mass was dissected from septum with respatorium, it sized was $1 \times 1 \times 0.5 \mathrm{~cm}$. Bleeding was coming from lession bed and treated with applied tamponade.

- Rest of mass at lession bed was cleaned and cutted with curretage and cutting forsep.

- $\mathrm{AgNO}_{3}$ was applied on lession bed to stop bleeding.

- Evaluation : no sign of cartilage destruction.

- Then nasal packing was set up in left nasal cavity.

- Oral packing was released and operation had been finished.

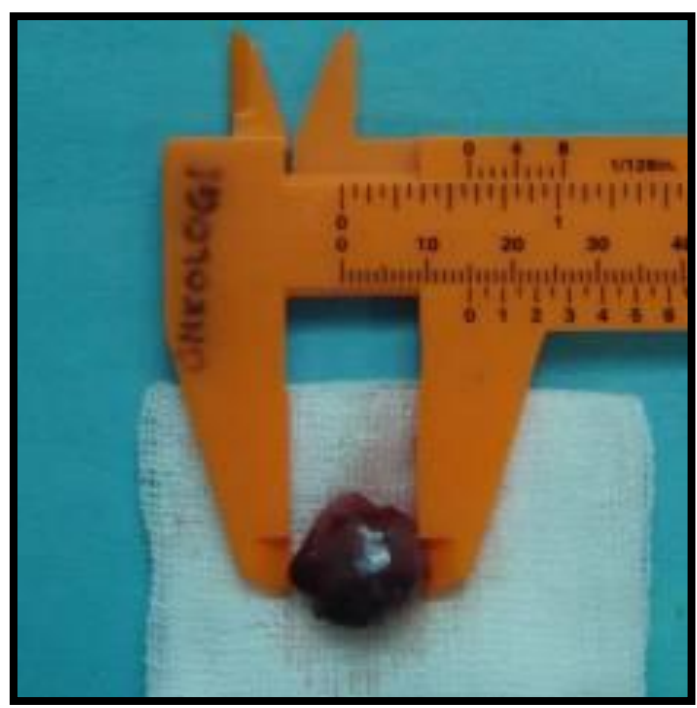

Figure 3. Haemangioma after extirpation 
After operation the patient was given cefixime $2 \times 50 \mathrm{mg}$ and ibuprofen $3 \times 200 \mathrm{mg}$ orally.

Three days later the nasal packing was removed and no active bleeding at left nasal cavity, clotting at extirpation site, inferior and medial turbinate eutrophy, no sinechia, no septal perforation. Working diagnosis was post extirpation suspected haemangioma nasal septum and patient was discharge with therapy cefixime $2 \times 50 \mathrm{mg}$.

Patient controlled to ENT out patient after 1 week. From examination there was no bleeding from nose, no nasal obstruction, no pain, no fever. From left nasal cavity there was clotting at extirpation site at anterior septal, no sinechia. Patient was diagnosed with post extirpation suspected haemangioma nasal septum and give therapy cefixime $2 \times 50 \mathrm{mg}$.

On December $14^{\text {th }} 2010$, histopatological analysis (PJ-1272-10) founded : stroma was swollen contain with little cavity which layered by endotel contain with eritrocyte. There was extensive bleeding. The surface folded by atrophic thin epitel. Conclusion : capillary haemangioma.

After 4 months, there was no sign of recurrence at nasal septum.

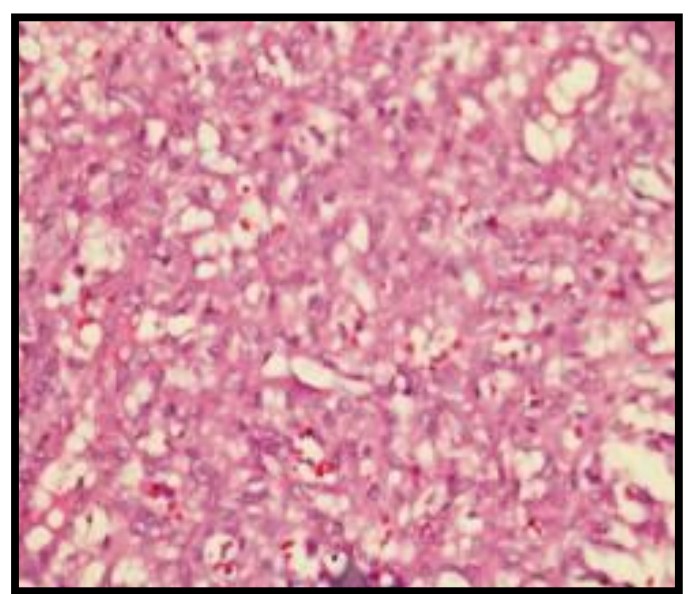

Figure 4. Histological appearance shows eritrocyte in little cavity layered by endotel

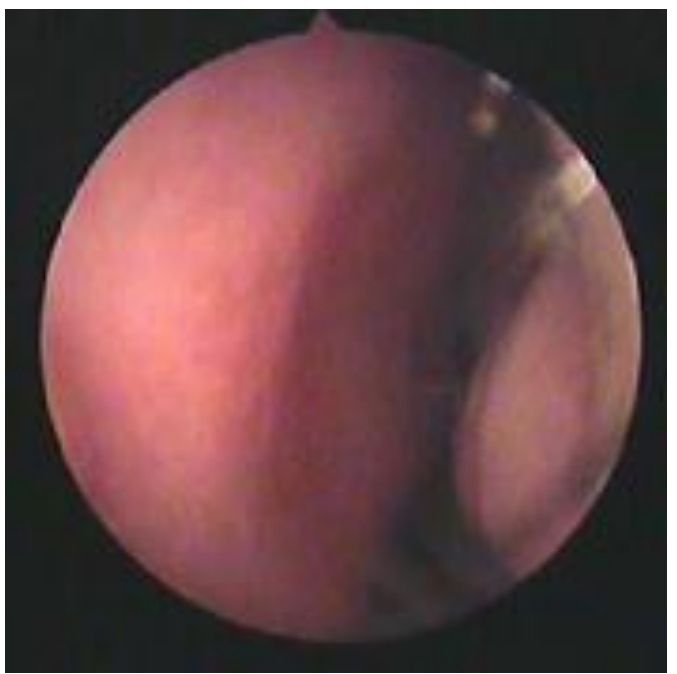

Figure 5. There is no sign of recurrent at anterior septum

\section{DISCUSSION}

Haemangiomas are benign tumours that originate in the vascular tissues of skin, mucosa, bone, muscles and glands. It growth rapidly, regress slowly and never recur. In the biologic classification proposed by Mulliken \& Glowacki in 1982, haemangiomas are defined as vascular tumours that enlarged by rapid cellular proliferation. They are classified as capillary, cavernous, and mixed lesions. There are 3 stages in the life cycle of a haemangioma : (1) the proliferating phase (0-1 year of age), (2) the involuting phase (1-5 years of age) and (3) the involuted phase (> 5 years of age). Usually, congenital lesions are located on the skin or oral mucosa while the nasal cavity and paranasal sinuses are uncommon sites for haemangiomas. Nasal cavity haemangioma is extraordinarily rare in children. Only nine cases have been reported in the English literature between 1985 and 2005 . $^{2,3,4,6,8}$

Haemangiomas account for about $20 \%$ of all benign neoplasms of the nasal cavity. Haemangioma of the nasal cavity occurs most commonly on the septum $(65 \%)$, lateral wall $(18 \%)$, and vestibule $(16 \%)$. $4,5,7,9$

No mechanism for the development of capillary haemangioma has so far been defined. However, trauma, hormonal influences, viral oncogenes, underlying microscopic arteriovenous malformations, and the production of angiogenic growth factors have been suspected to act in the pathogenesis. Puxeddu et al found that predispossing factors such as nasal trauma were identified in $15 \%$ from 40 patients and pregnancy were identified in 2 patients $(5 \%)$. Meanwhile Nair also hypothesized that microtrauma or chronic iritation in nasal cavity as aetiology of haemangiomas, but in this patient, none of these potential etiological factors was determined. ${ }^{7,8,10}$

Epistaxis in childhood are generally repeated, short-lasting and self-limiting. However, they are a cause of significant distress to children and their parents and result in significant morbidity and hospital referral. Several etiology have been found that cause epistaxis in childhood such as trauma, inflamation, haematological, neoplastic and vascular abnormalities. $^{11}$

This patient have symptom recurrent unilateral epistaxis and left nasal obstruction. Puxeddu et al founded that in 40 haemangiomas patients, the presenting symptoms, which had been present for a period varying from 1 week to 5 years, were unilateral epistaxis (95\%), nasal obstruction (35\%), rhinorrhea $(10 \%)$, facial pain $(7.5 \%)$, headache $(4 \%)$, and hyposmia (4\%) alone or in different associations. $7,8,9$

On examination, haemangioma presented at left anterior septum as a reddish mass, almost closed anterior nostril, rubbery, no fluctuation, no pain, no ulseration. This clinical founding proper with Puxeddu et al which is says that, the lesion was found to originate from the nasal septum in $22(55 \%)$ patients, the nasal vestibule in $7(17.5 \%)$ patients, the inferior turbinate in $5(12.5 \%)$ patients, and the middle turbinate and the mucosa covering the uncinate process in $3(7.5 \%)$ cases each. Same as nedev, lessions vary in size from 1 to $8 \mathrm{~cm}$ and mainly involve the nasal septum (in $45 \%$ ) and the nasal vestibule (in $17,5 \%$ of the cases). This examination also support 
with CT founding that says that the mass was in the nasal cavity but it did not clarify the source of the mass. $4,8,12$

Haemangiomas should be distinguished from granulation tissue, telangiectasia, vascular malformations, vascular polyps, papillary endothelial hyperplasia, angiofibroma, angiolymphoid hyperplasia with eosinophilia, glomus tumour, lymphangioma, Kaposi sarcoma, and angiosarcoma. Haemangioma can be distinguished from granulation tissue by the lobular arrangement of the capillaries in the former and the more parallel arrangement of vessels in the latter. The distinction between a haemangioma and telangiectasia may be difficult but is facilitated in a patient with a known family history of hereditary haemorrhagic telangiectasia (Osler-Weber-Rendu syndrome). $1,4,7,8,10,12$

Ahmad and Norie prove that nasal cavity vascular's tumour can be mistaken with juvenile nasopharyngeal angiofibroma but after angiography they didn't find any significant feeding vessel supplying the tumour. Meanwhile Puxeddu also state that differential diagnosis may pose challenging problems in large lessions where it can be misdiagnosed as angiofibroma and low grade angiosarcoma. Because of that information obtained with imaging techniques, along with the age and gender of the patient, help to make a correct diagnosis of angiofibroma and differentiation of haemangioma from other hypervascularized lesions. ${ }^{1,4,8,10,13}$

Based on histopathology this tumor can be divided into capillary and cavernous types based on the size of the blood vessels. Haemangiomatosis is a more diffuse lesion often involving contiguous structures. Cavernous haemangiomas are frequently intraosseous or involve the turbinates or lateral nasal wall. They are composed of multiple, large thin-walled, dilated blood vessels separated by scant fibrous stroma. ${ }^{1,2,4,8}$

The management of haemangiomas continues to be an area of considerable controversy. The treatment of congenital vascular anomalies is based on an understanding of the clinical behaviour and natural history of individual lesions, the localization and size of the neoplasm. Some treatment had been introduced such as injection of sclerosing solution, intralesional injection of steroid, interferon application, laser therapy, cryosurgery, cytostatic, embolization and surgical treatment. $4,8,14,15,16$

Haemangiomas are generally easy to remove, although larger tumours may be complicated by excessive bleeding. They should be removed in all ages, especially in children since aplasia of the nasal cartilages may cause eventual disfigurement. If the tumour is pregnancy- related, regression will often occur after parturition. Multiple recurrences are more common in children if the lesional bed is not completely eradicated. ${ }^{4,8,10}$

Total excision of the lesion by either classical or endoscopic surgery techniques has been recommended. The endoscopic surgery provides better visualization of the mass and surrounding anatomy, thus allowing the surgeon to remove the mass completely without an external incision. In the very recent literature, all patients with a large lesion have been managed without preoperative embolization and none has experienced blood loss requiring transfusion. ${ }^{12,13,15}$
The application of endonasal endoscopic surgery is constantly evolving. One of the advantages of this technique is that it does not involving any facial skin incision and is better tolerated by the patient. This surgical approach involves a shorter hospitalization. This technique was once considered to have limitation on the vascular tumor because endoscopic removal of such tumor could be difficult due to uncontrolled bleeding which could hamper visualization and margin assessment. Kelley TF state that with careful preoperative planning and conservative surgical technique, these highly vascular tumors can be safely and effectively removed with an endoscopic approach. $7,8,12,13,15$

The application of $\mathrm{AgNO}_{3}$ to stop bleeding was succesfull while operation. Many treatment can apply to treat bleeding such as cauterization, using of laser or embolization. But in recent years many clinicians found that this tumour can be managed without preoperative embolization and none has experienced blood loss requiring tranfusion. $7,15,16$

After 4 months follow up there is no recurrent of haemangioma. Some studies and cases of haemangioma reported that recurrences are uncommon if there is no residual at lesion bed. ${ }^{4,6,7,8,15}$

\section{LITERATURES}

1. J.C.Fanburg-Smith, L.D.R. Thompson. Benign soft tissue tumours. In: Barnes L, Eveson JW, eds. World Health Organization Classification of tumours, pathology and genetics head and neck tumours. Lyon, 2005

2. Valencia MP, Castillo M. Congenital and acquired lesions of the nasal septum: A practical guided for differential diagnosis. Radiographics 2008;28:205-33

3. Duvvuri U, Carrau RL, Kassam AB. Vascular tumours of the head and neck. In: Byron BJ, Jonas JT, Shawn ND, eds. Head and neck surgery-otolaryngology, 4th edition. Pittsburgh. Lippincott Williams \& Wilkins, 2006; p: 1812-25

4. Nedev P. Lobular capillary haemangioma of the nasal cavity in children - Literature survey and case report. Trakia Journal of Sciences 2008;6(1): 63-7.

5. Zarrinneshan A, Zapanta P, Wall SJ. Nasal pyogenic granuloma. Otolaryngology-Head and Neck Surgery 2007; 136: 130-1

6. Marler JJ, Mulliken JB. Current management of hemangiomas and vascular malformations. Clin plastic surg 2005;32:99-116

7. Takeda K, Takenaka Y, Hashimoto M. Intraosseous haemangioma of the inferior turbinate. Case report in medicine, 2010.

8. Puxeddu P, Berlucci $\mathrm{M}$, et al. Lobular capillary haemangioma of the nasal cavity: A retrospective study on 40 patients. Am J Rhinol 2006; 20: 480-4

9. Genc S, Kurkcuoglu $S$ et al. Giant lobular capillary haemangioma of the nasal septum. Turk J Med Sci 2009; 39 (2): 325-8

10. Nair S, Bahal MA, Bhadauria. Lobular capillary hemangioma of nasal cavity. MJAFI 2008; 64:270-271

11. Carrie S. Nasal forign bodies, epistaxis and nasal trauma. In: Graham JM, Scadding GK, Bull PD eds. Pediatrics ENT. Springer 2007; p. $285-9$ 
12. Archontaki M, Stamou, et al. Cavernous haemangioma of the left nasal cavity. Acta otorhinolaryngologica italica 2008;28:309-11

13. Ahmad R, Norie A. Endonasal endoscopic resection of intranasal haemangioma. Med $\mathrm{J}$ Malaysia 2006; 61(5)

14. Berlien HP. Principles of Therapy of Infantile Hemangiomas and Other Congenital Vascular Tumors of the Newborns and Infants. In: Matassi R, Loose DA, Vaghi M, eds. Hemangiomas and vascular malformations-an atlas of diagnosis and treatment. Springer verlag Italia, 2009. p: 4984.
15. Kelley TF. Endoscopic management of an intranasal haemangioma: A case report and literature review. Otolaryngol Head Neck Surg 2003;128:595-7.

16. Andronikou, S, Mandelstam S, Fasulakis, S. $\mathrm{MRI}$ and preoperative embolization of a nasal cavity haemangioma in a child. Australasian Radiology 2003;47:386-8. 